\title{
Changing home and workplace in Victorian London: the life of Henry Jaques, shirtmaker
}

\author{
COLIN G. POOLEY and JEAN TURNBULL * \\ Dept of Geography, Lancaster University, Lancaster, LA1 4YB
}

\begin{abstract}
The paper uses unusually rich evidence from a manuscript life history written in 1901 from personal diaries to explore the changing relationship between home and workplace in Victorian London. The life history of Henry Jaques demonstrates the way in which decisions about employment and residence were related both to each other and to stages of the family life course. The uncertainty of work, lack of income to support a growing family, rising aspirations, the constant threat of illness, the ease of moving between rented property, close ties between home and workplace, the stresses produced by home working, and the attractions of suburbanization all interacted to shape the residential and employment history of Jaques and his family. The themes exemplified by this detailed life history were also relevant to many other people. Evidence collected from a large-scale project on lifetime residential histories is used to place the experiences of Henry Jaques in a broader context, and to show how they related to the changing social and economic structure of Victorian London.
\end{abstract}

One aspect of Victorian life about which we know relatively little is the changing relationship between home and workplace. A small number of studies of intra-urban residential mobility have demonstrated the extent to which many people moved frequently between similar properties within quite a small area, ${ }^{1}$ but the relationship of such movement to employment change has rarely been explored, and there are few detailed studies of the changing journey to work in the nineteenth century. ${ }^{2}$

- We are indebted to A.M. Giller for providing a copy of the Henry Jaques manuscript and allowing us to quote from it, to all the family historians and genealogists who provided data for the wider research project, and to The Nuffield Foundation and the ESRC for providing financial support for the research. Barry Rowlingson provided invaluable help with GIS and Nicola Higgitt prepared the maps for publication. Many thanks to David Green who commented on an earlier version of the paper.

1 R. Dennis, 'Inter-censal mobility in a Victorian city', Transactions of the Institute of British Geographers, n.s., 2 (1977), 349-63; C.G. Pooley, 'Residential mobility in the Victorian city', Transactions of the Institute of British Geographers, n.s., 4 (1979), 258-77; D. Green, From Artisans to Paupers (Aldershot, 1995), 91-4.

2 A. Warnes, 'Early separation of homes from workplaces and the urban structure of Chorley, 1780-1850', Transactions of the Historic Society of Lancashire and Cheshire, 122 (1970), 105-35; J. Vance, 'Housing the worker. the employment linkage as a force in urban 
It is usually assumed that for most people in Victorian Britain it was both necessary and convenient to minimize the distance between home and workplace. Most places were 'walking cities', ${ }^{3}$ and even in late nineteenthcentury London it was estimated that over three-quarters of trade unionists in South London used no public transport for their journey to and from work. ${ }^{4}$ A short journey to work was required both because many trades were casual, and there was thus a strong imperative to be part of a community which knew when work was available, ${ }^{5}$ especially on the docks, ${ }^{6}$ and because of the inability of most working people to afford public transport. ${ }^{7}$ In the twentieth century rising real incomes and relatively cheap public transport have meant that the journey to work has lengthened, 8 that a change in workplace is less likely to lead to a change in residence, and that moves for housing and family reasons can occur without the constraint of needing to be close to employment. ${ }^{9}$

The link between home and workplace was also closely related to the life course, ${ }^{10}$ with different demands made on both employment and

structure', Economic Geography, 42 (1966), 294-325; idem, 'Housing the worker: determinative and contingent ties in nineteenth-century Birmingham', Economic Geography, 43 (1967), 95-127; R. Dennis, English Industrial Cities of the Nineteenth Century (Cambridge, 1984), 138-40; D. Green, 'Distance to work in Victorian London: a case study of Henry Poole, bespoke tailors', Business History, 30 (1988), 179-94; M. Barke, 'The middle-class journey to work in Newcastle-upon-Tyne, 1850-1913', Journal of Transport History, 12 (1991), 107-34.

3 M. Daunton, Coal Metropolis: Cardiff 1870-1914 (Leicester, 1977), 127.

'H.J. Dyos, 'Workmen's fares in south London, 1860-1914', The Journal of Transport History, 1 (1953), 15; See also T.C. Barker and M. Robbins, A History of London Transport, vol. 1 (London, 1963).

5 H.J. Dyos, 'Railways and housing in Victorian Britain', The Jourmal of Transport History, 2 (1955), 67-9; D. Green, 'Street trading in London: a case study of casual labour, 1830-60', in J.H. Johnson and C.G. Pooley (eds), The Structure of Nineteenth-Century Cities (London, 1982), 129-52; D. Green, 'The metropolitan economy: continuity and change 1800-1939', in K. Hoggart and D. Green (eds), London: A New Metropolitan Geography (London, 1991), 8-33.

6 J. Lovell, Stevedores and Dockers: A Study of Trade Unionism in the Port of London, 1870-1914 (London, 1969).

7 Dyos, 'Workmen's fares'; H.J. Dyos and D. Aldcroft, British Transport: An Economic Suroey From the Seventeenth Century to the Twentieth (Harmondsworth, 1974); Barker and Robbins, London Transport.

8 J. Westergaard, 'Journeys to work in the London region', Town Planning Reoiew, 28 (1957), 37-62; R. Lawton, The journey to work in England and Wales: forty years of change', Tidjschrift ooor Economische en Sociale Geographie, 44 (1963), 61-9; idem, The journey to work in Britain: some trends and problems', Regional Studies, 2 (1968), 27-40; P. Daniels, 'Employment decentralization and the journey to work', Area, 1 (1970), 47-51; A. Warnes, 'Estimates of journey to work distances from census statistics', Regional Studies, 6 (1972), 315-26; W. Davies and T. Musson, 'Spatial patterns of commuting in South Wales, 1951-71', Regional Studies, 12 (1978), 353-66.

9 On migration trends see D. Coleman and J. Salt, The British Population: Patterns, Trends and Processes (Oxford, 1992), 395-432; T. Champion and T. Fielding (eds), Migration Processes and Patterns. Vol. 1: Research Progress and Prospects (London, 1992); J. Stillwell, P. Rees and P. Boden (eds), Migration Processes and Patterns. Vol. 2: Population Redistribution in the United Kingdom (London, 1992).

10 P. Rossi, Why Families Move: A Study in the Social Psychology of Urban Residential Mobility (Glencoe, Ill, 1955); Champion and Fielding, Migration Processes and Patterns, 165-87. 
home at particular stages of the life cycle. In the nineteenth century many single men and women would have lived and worked in the same place, apprenticed to a master or as a farm or domestic servant. ${ }^{11}$ Marriage and family commitments would have meant the need for greater independence, a higher disposable income and an independent home. ${ }^{12}$ Thus decisions about the location of home and workplace, and the relationship between them, changed over the life course and cannot be seen as independent of broader changes within society - for instance the decline in farm and domestic servants - which affected patterns of work and living.

This paper focuses primarily on the life history of one man, Henry Jaques, to explore some aspects of the relationship between home and workplace in Victorian London. Analysis examines the reasons why residential and occupational change occurred, the links between them and the life course of individual actors, and the impact of such changes on the Jaques household. Following a brief assessment of the source on which the paper is based, and an introductory resume of Jaques's life, analysis is focused on three reasonably distinct life-cycle phases: his experiences as a young single adult, his early married life, and his more mature married life moving into old age. It is not suggested that the evidence presented in this paper is necessarily typical of a larger population, but detailed analysis of one life history does raise many general issues of much wider applicability. These points are returned to in a concluding discussion where the experiences of Henry Jaques are related to other evidence about changes in home and workplace in Victorian London.

\section{The context}

In the second half of the nineteenth century London was a sprawling metropolis, with the County of London covering an area of some 74,672 acres within its administrative boundaries, and with a population of over 4.2 million in $1891 .{ }^{13}$ It can be suggested that, more than most Victorian cities, London was not a single settlement, but rather that it consisted of an agglomeration of separate communities each with their own identity. ${ }^{14}$ During the nineteenth century there was increasing

11 On the nineteenth-century labour market see: P. Joyce, 'Work', in F.M.L. Thompson (ed.), The Cambridge Social History of Britain, 1750-1950, vol. 2 (Cambridge, 1990), 131-94; M. Daunton, Progress and Poverty: An Economic and Social History of Britain, 1700-1850 (Oxford, 1995), 125-386. Specifically on London, see G. Stedman Jones, Outcast London: A Study in the Relationship between Classes in Victorian Society (Oxford, 1971).

12 On changes in family and household structures see: $M$. Anderson, Approaches to the History of the Western Family, 1500-1914 (London, 1980); L. Davidoff, "The family in Britain', in Thompson, Cambridge Social History, vol. 2, 71-130; M. Anderson, F. Bechhofer and J. Gershuny, The Social and Political Economy of the Household (Oxford, 1994).

13 Census of England and Wales (1891).

14 On nineteenth-century London see: A. Briggs, Victorian Cities (London, 1963), 311-60; 
separation of classes and segregation of neighbourhoods ${ }^{15}$ and, given the size of London, it is likely that most individuals in the nineteenth century identified more with their local community than with the city as a whole. These perceptions inevitably influenced decisions about where people worked and lived.

The areas in which Jaques lived were mainly to the north and east of the City, focusing on Islington, Mile End, and the expanding suburban district of Forest Gate (West Ham). The population of a borough like Islington grew rapidly in the nineteenth century from 10,212 in 1801 to 95,329 in 1851 , and 319,143 in 1891 . It was thus comparable in population to the major provincial cities of England (for instance, Sheffield had a population of 324,000 in 1891 and at this date only five English provincial cities exceeded the population of Islington). ${ }^{16}$ Throughout much of this area housing densities were high, with most families living in closely packed terraces, often in rooms in a large house occupied by several families. ${ }^{17}$ The worst districts included zones in which Charles Booth estimated that over 60 per cent of the population lived in poverty, and contained neighbourhoods with some of the worst reputations in the city, ${ }^{18}$ though in the northern part of Islington only 20 per cent were in poverty according to Booth's criteria. ${ }^{19}$

The expanding residential suburb of West Ham (which included Forest Gate) grew even faster than Islington in the second half of the nineteenth century. In 1851 it was only a little over a third of the size of Islington, with a population of 34,395 , but by 1891 it had mushroomed to 365,134 , exceeding the population of Islington and all but four of England's provincial towns, and larger than the Scottish capital Edinburgh. ${ }^{20}$ Most housing in Forest Gate was thus relatively new and initially consisted of better quality terraces and low density villas; but

Stedman-Jones, Outcast London; D.J. Olsen, The Growth of Victorian London (London, 1976); K. Young and P. Garside, Metropolitan London: Politics and Urban Change, 1837-1981 (London, 1982); P.J. Waller, Town, City and Nation. England 1850-1914 (Oxford, 1983), 24-67; H. Clout and P. Wood (eds), London: Problems of Change (London, 1986), 23-41; P. Garside, 'London and the Home Counties', in Thompson, Cambridge Social History, vol. 1, 471-540; Green, 'Metropolitan economy'; L. Schwarz, London in the Age of Industrialization (Cambridge, 1992); R. Porter, London: A Social History (London, 1994); Green, From Artisans to Paupers.

15 Olsen, Victorian London, 16-35.

16 Census of Great Britain (1851); Census of England and Wales (1891).

17 See Stedman Jones, Outcast London, 159-230; D. Green and A. Parton, 'Slums and slum life in Victorian England: London and Birmingham at mid-century', in S.M. Gaskell (ed.), Slums (Leicester, 1990), 17-91; W.J. Fishman, East End 1888 (London, 1988).

18 Fishman, East End; Stedman Jones, Outcast London; J.White, Rothschild Buildings. Life in an East End Tenement Block, 1887-1920 (London, 1980). See also the work of contemporary observers and writers including. $\mathrm{H}$. Mayhew, London Labour and the London Poor (London, 1861); C. Booth, Life and Labour of the People in London, vol. 1 (London, 1889); J. Greenwood, In Strange Company (London, 1873); I. London, People of the Abyss (London, 1902).

19 Booth, Life and Labour, 63-72.

20 Census of Great Britain (1851); Census of England and Wales (1891); Census of Scotland (1891). 
housing densities increased and quality declined as the century progressed, and by the twentieth century this area was generating social concern. ${ }^{21}$

The employment structure of London was diverse with no single industry dominating the labour market. ${ }^{22}$ In 1861 some 45.1 per cent of the employed population of Greater London were in service trades supporting the large urban population of the conurbation and its associated commercial activities; 31.7 per cent worked in manufacturing industry, mostly a wide range of small-scale activities often based on workshop and home working; 9.4 per cent were employed in transportrelated activities, including the London docks; and 6.6 per cent in construction. ${ }^{23}$ One of the larger manufacturing employment sectors was the clothing trade, based on the bespoke trade of the West End and, especially, the mainly wholesale trade of the East End of London. ${ }^{24}$ This included a wide range of hosiery and drapery enterprises, tailors, shirtmakers and the like, most of whom worked from home or in small workshops, and in which working conditions and rates of pay were amongst the poorest in the country. ${ }^{25}$ These activities fed into both a local retail trade which served the population of the capital, and a more wide-ranging wholesale trade with London-based clothes manufacturers supplying many parts of Britain and some export markets. ${ }^{26}$ It is in the context of these housing and working conditions that Henry Jaques lived his life.

\section{The life story of Henry Jaques}

Data for the bulk of this paper are drawn from the 'Life story of Henry Louis Jaques' which was compiled in 1901 when Jaques was 59 years old, using diaries which he had kept and supplemented from memory. ${ }^{27}$ The document appears to give a full and accurate account of his life - the

21 E.G. Howarth and M. Wilson (eds), West Ham: A Study in Social and Industrial Problems (New York, 1980; 1st pub. London, 1907). On London suburbs more generally see H.J. Dyos, Victorian Suburb: A Study of the Growth of Camberwell (Leicester, 1961); A. Jackson, Semi-Detached London: Suburban Development, Life and Transport, 1900-1939 (London, 1973); F.M.L. Thompson, The Rise of Suburbia (Leicester, 1982).

22 P. Hall, The Industries of London Since 1861 (London, 1962); Green, Metropolitan economy". But see also D. Green, "The nineteenth-century metropolitan economy: a revisionist interpretation', London Journal, 21 (1996), 9-26.

23 Green, 'Metropolitan economy', 15; see also Hall, Industries of London, 183-5.

24 Fishman, East End; Hall, Industries of London; W. Besant, East London (New York, 1980; 1st pub. London, 1901).

25 J. Morris, Women Workers and the Sweated Trades (Aldershot, 1986); J. Schmiechen, Sweated Industries and Sweated Labour: The London Clothing Trades, 1860-1914 (Urbana, Il, 1984); D. Bythell, The Sweated Trades: Outwork in Nineteenth-Century Britain (London, 1978); R. Mudie-Smith, Sweated Industries: A Handbook of the 'Daily News' Exhibition (New York, 1980; 1st pub. London, 1906); Report from the Select Committee on Home Work (HMSO, 1906).

26 Green, Metropolitan economy?.

27 The original manuscript is in the possession of A.M. Giller. This paper is based mainly 
typescript version covering ninety-eight pages - and his motives for writing the account seem straightforward. In his introduction he writes:

For very many years it had occurred to me that some such record as this should be written to be handed down to my dear dear children, and perused by them when the hand which writes it is still in the tomb.28

Inevitably some parts of the manuscript are fuller than others, and more detail is given for earlier periods of his life when he kept a detailed daily diary:

A diary was kept for many years, and full use thereof will be made for the following pages. But life's duties becoming more onerous as the years fled by, the daily Diary had to go, not without many regrets ...29

Later stages of his life are dealt with more briefly, but he still records key events in considerable detail, together with more reflective comments on his life. The accuracy of the diary can be checked by cross-referencing key life events with information in the records of the Registrar General, census enumerators' books, and other contemporary sources. Where this has been done the life history has been shown to provide a detailed and accurate record..$^{30}$

There are many general problems associated with the use of sources such as this. First, it can be suggested that any individual who kept a regular diary and compiled a life history for the consumption of his family was atypical of the majority of ordinary Victorian men and women. We should question the motives as to why he should want to record his life, whether there were particular aspects that he was keen to stress at the expense of other evidence, and the extent to which the literacy and leisure time which made it possible for him to record his life history separated him from his contemporaries. It should also be stressed that, even assuming the intention of the author was to write an accurate and genuine account of his life (as did seem to be the case with Henry Jaques), the record that is provided will have been filtered through the eyes of time, and some detail will have been lost or distorted by selective memories. This problem is no greater than dealing with most other manuscript sources, or with oral evidence, but it should be borne in mind when interpreting the written record. Furthermore, the interpretation placed on the life history will be further filtered through the perceptions of the researchers. This paper is inevitably a selective interpretation of evidence available in the life history. Despite such problems, similar documents have been widely used in a variety of types

on a typescript of the manuscript kindly supplied by A.M. Giller. All page references refer to the typescript.

28 'Life story', 1.

29 Ibid.

${ }^{30}$ The validity of the document has been checked against a wide range of sources by A.M. Giller, and we have double-checked some items. 
of historical research. ${ }^{31}$ The particular value of the source for this paper is that it provides valuable insights into a neglected area of historical research: the changing relationship between home and workplace and their links to the life course.

It is first necessary to sketch an outline of the life of Henry Jaques. His father, Auguste Jaques, was a Swiss watchmaker who emigrated to London in 1828. Here he married Eliza Barber who came from Sandwich in Kent. His wife died following the birth of her first child, and Auguste then married Eliza's elder sister. The Jaques were living in the Islington area of London where Auguste was working as a watchmaker when Henry was born into the family in 1842, the second of seven children to be born to his mother between 1840 and 1852. Henry attended a Dame School and, for two years (1853-54), Barnsbury National British School. He records that he enjoyed school and regretted leaving at the age of 12 to begin work as an errand boy. Details of Henry's career and residential moves as an adult are examined in detail below. In total he had some 21 different occupations and moved 31 times during his lifetime, 26 of these moves occurring after he left home in 1858 (at the age of 16) to be apprenticed to a draper. Henry Jaques married Lizzie Bidwell in 1864 and they had a total of fourteen children between 1865 and 1888. The life history ends in 1900, but Henry lived until 1907 when he died at his home in Forest Gate at the age of 65.

\section{Home and workplace for a young single man in East London}

Migration decisions are closely related to age and life-cycle stage. For the first twelve years of his life Henry Jaques was a dependent member of his household and moved five times with his family to houses in and around Islington in north London (Table 1, Figures 1 and 2). Although it was not unusual for a 12-year-old boy to leave home to be apprenticed to a trade in the 1850 s, the intention of the Jaques family was eventually to apprentice Henry to the watchmaking business of his father. Henry thus remained at home, largely dependent on his parents, when he left school in 1854 . He was not immediately apprenticed to the watchmaking trade due to financial problems at home, and instead he took a position as an errand boy to an hourglass maker. This was a financial decision by the

31 J. Marshall (ed.), The Autobiography of William Stout of Lancaster (Manchester, 1967); J. Burnett, Useful Toil (London, 1974); R. Lawton and C.G. Pooley, 'David Brindley's Liverpool: an aspect of urban society in the 1880s', Transactions of the Historic Society of Lancashire and Cheshire, 125 (1975), 149-68; A. Macfarlene (ed.), The Diary of Ralph Josselin, 1616-83 (Oxford, 1976); D. Vincent, Bread, Knowledge and Freedom: A Study of Nineteenth Century Working-Class Autobiography (London, 1981); J. Burnett, D. Vincent and D. Mayall (eds), The Autobiography of the Working Class: An Annotated and Critical Bibliography (Brighton, 1984, 1987); H. Southall, 'Mobility, the artisan community and popular politics in early nineteenth-century England', in G. Kearns and C. Withers (eds), Urbanising Britain (Cambridge, 1991), 103-30; C.G. Pooley and S. D'Cruze, 'Migration and urbanization in north-west England, circa 1760-1830', Social History, 19 (1994), 339-58. 
family to enable him to contribute to the household income rather than be a drain on it, as would have been the case had he been apprenticed to his father. His initial wage as an errand boy was $5 s(25 p)$ per week of which he was allowed to keep $3 d(1.2 \mathrm{p})$. He was well received in his first job, his wage was soon increased to $6 s$ (30p) per week, and in addition he earned a further $1 / 6 d(7.5 p)$ per week helping a cheesemonger on a Saturday evening. After six months Henry moved to a better position running errands for a chronometer maker, and making $7 s$ (35p) per week (of which he kept $4 d(1.7 \mathrm{p})$ ). It seems likely that both these positions were secured through contacts which his father had as a watchmaker. Throughout this period Henry lived at home and his journey to work was short and on foot, as his work was close to his home in Islington. However, his errands regularly took him into the City and other parts of London.

As a 13-year-old child Henry had quite a protected life in that he still lived at home and his needs were provided for (albeit substantially from money he contributed to the household). His immaturity is emphasized by the events which led to his discharge from the chronometer makers in 1855. In his own words:

I rather disgraced myself here by loitering about when sent home with goods and it was really too bad. I was often gone 3 hours to a city journey when one should suffice and at last I mended my ways and went to the other extreme. I took to running all the way there and back, climbing on the backs of cabs and omnibuses, until in my anxiety to hasten and through running I lost an important and expensive piece of work, which led to my discharge. ${ }^{32}$

He was then apprenticed to his father to learn the watchmaking trade, and thus worked at home under close parental control, although he admits to continuing to loiter, stopping to play marbles with friends, and to losing some packages when sent on errands by his father to the City. What comes through most clearly is that, although in full-time employment and given some responsibility, he was still very much a child in the process of growing up.

Henry continued with his father for three years, but with decreasing interest in the work:

I loyally stuck to the work but through it all I felt it was not to be my line of business, I did not like the confinement and application. I was very fond of the detail of the work, but continually felt I should like to jump up and rush about at something. I wanted to be more active..$^{33}$

In May 1858, Henry's father recognised that his son, by now aged 16, was not cut out to be watchmaker, and he was apprenticed to a draper in Crosby Row, Southwark. This was the same firm that Henry's elder 


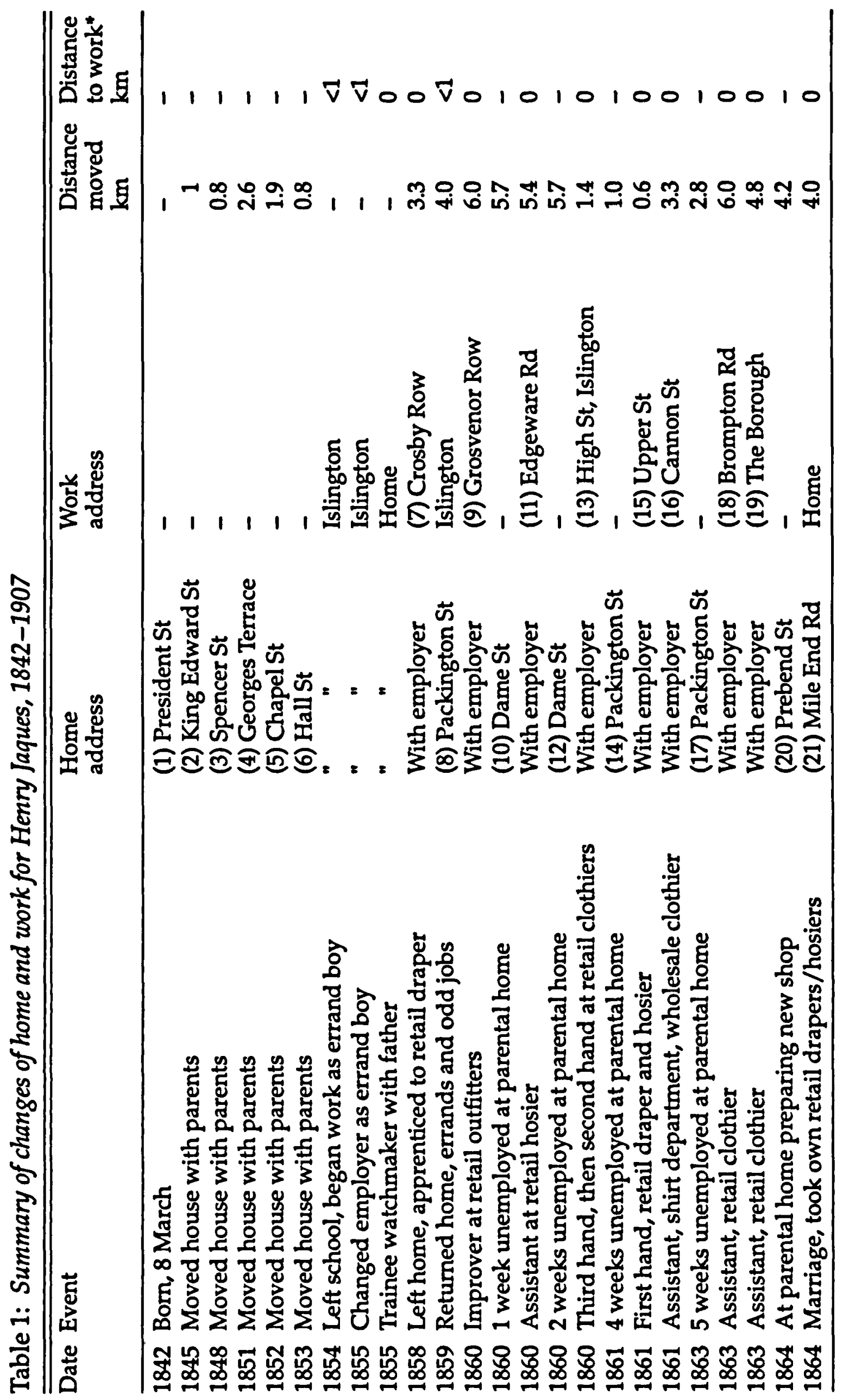




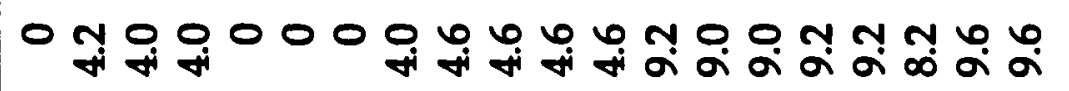

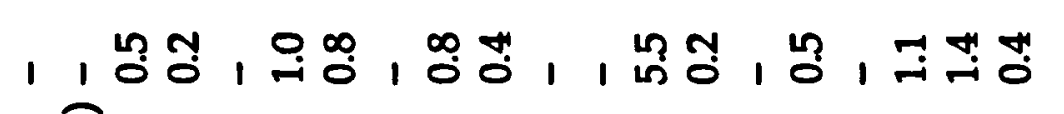

$$
\begin{aligned}
& \text { จ } \\
& \text { 点 落 }
\end{aligned}
$$

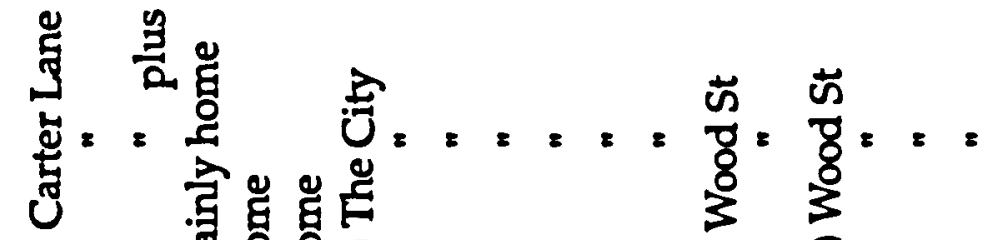

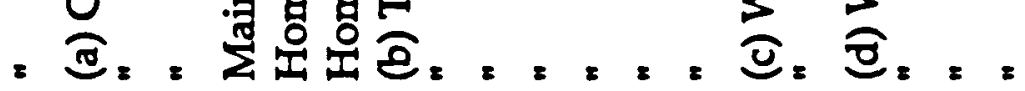

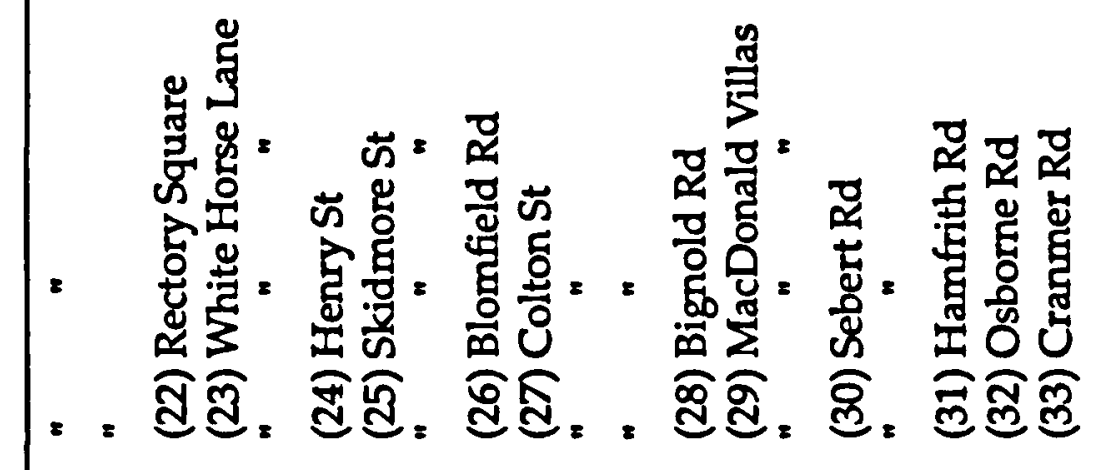
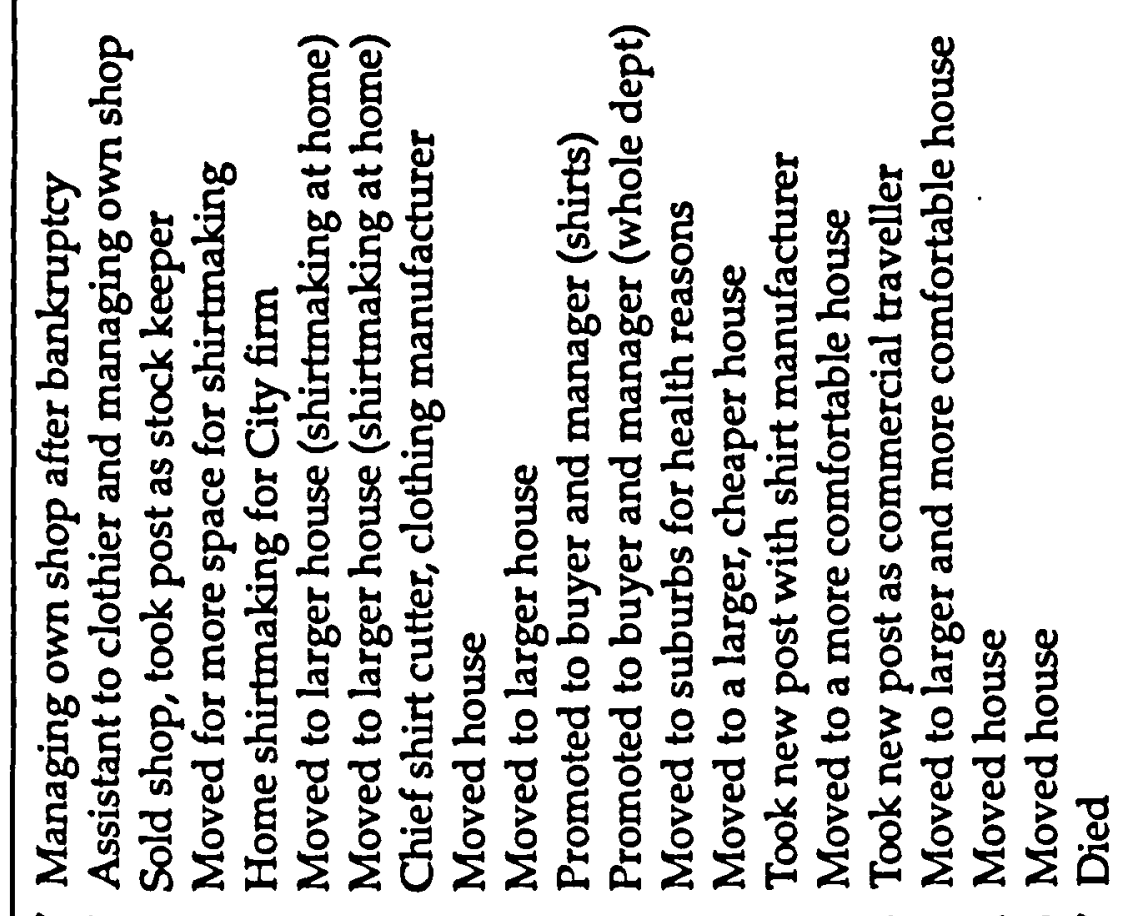

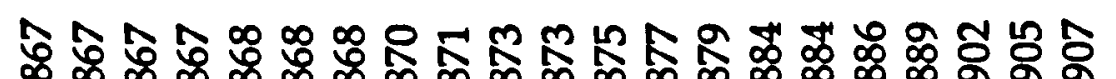




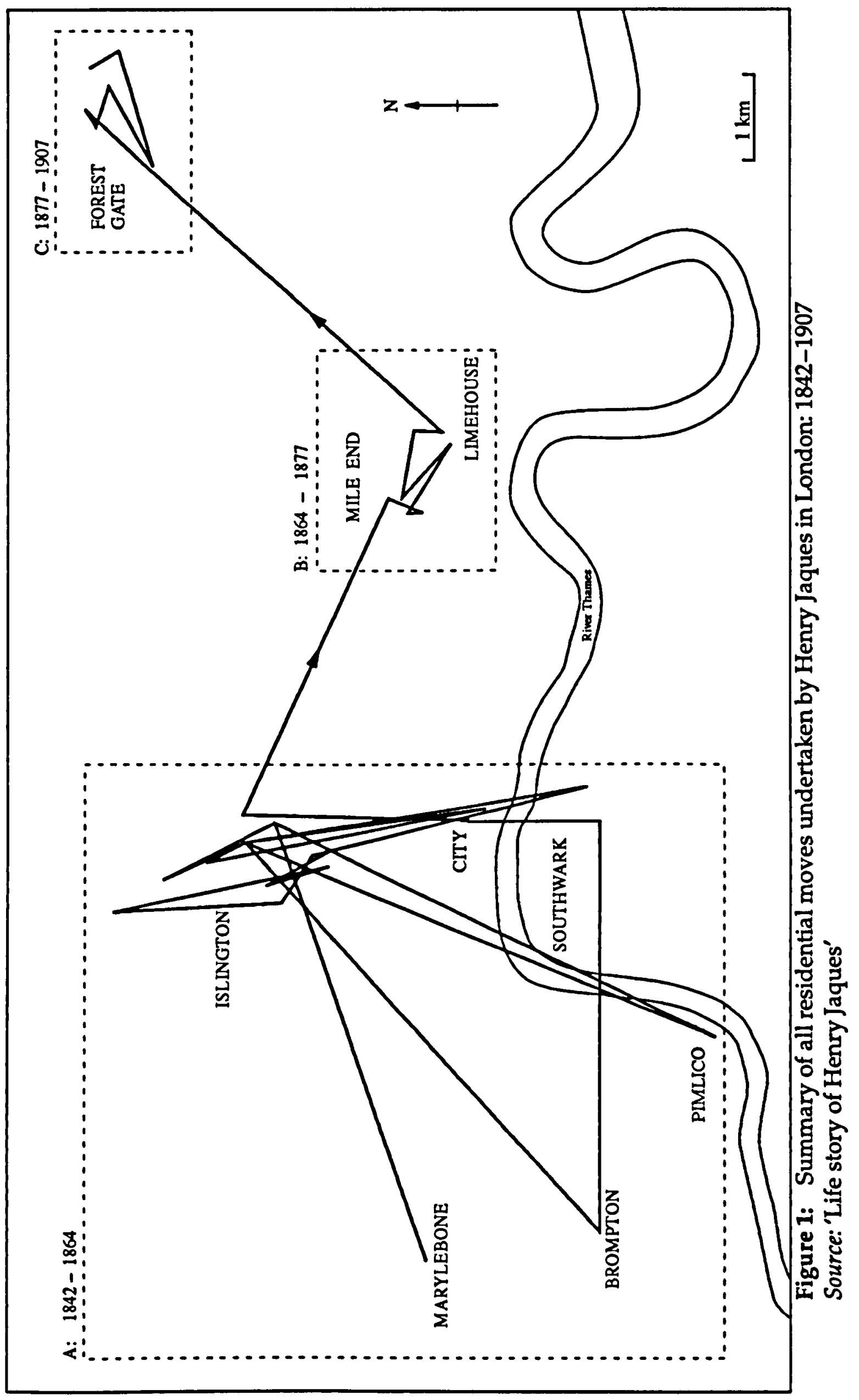




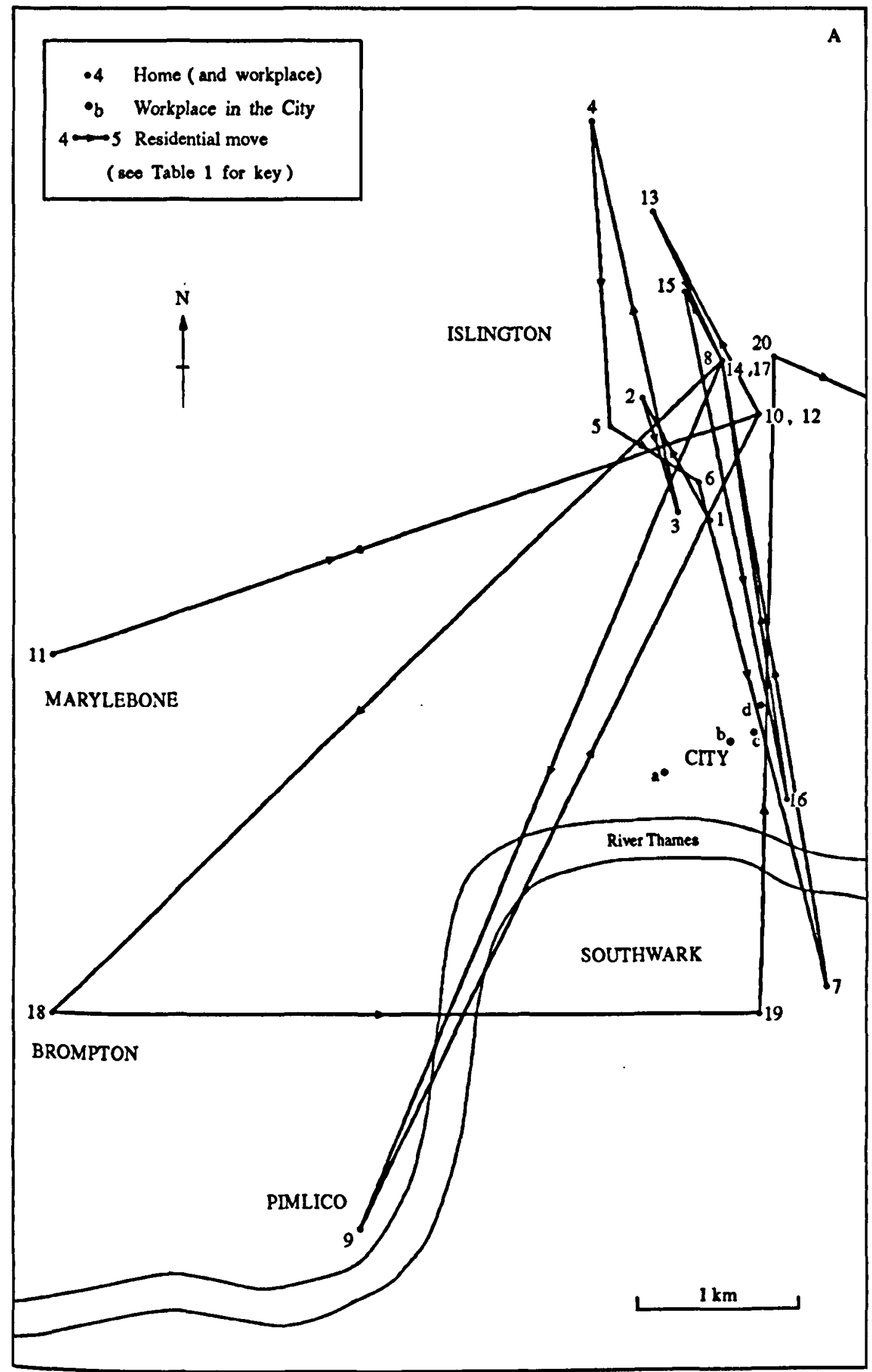

Figure 2: Details of residential moves undertaken by Henry Jaques mainly in Islington and central London, 1842-64 Source: 'Life story of Henry Jaques' 
brother had been apprenticed to and the family connection was important in securing the position. Very many boys in East London would have begun their careers in similar ways, working in some branch of the clothing trade based on home working, small workshops and retail businesses. ${ }^{34} \mathrm{As}$ an apprentice he lived with his employers (sleeping in a small bed in the corner of his master's bedroom) and returned home to see his parents every Sunday. Although less than four kilometres from his parental home, the move took him south of the Thames and his mother was not entirely happy about him leaving home:

I cannot say that parting from those at home caused me any great sorrow. I felt most for my mother - and she felt my going away acutely. As for me I was full of anticipation. ${ }^{35}$

After a trial of one month he was indentured for three years without salary, but with pocket money of $2 s$ per week 'if I was a good boy'. ${ }^{36}$ Working hours were long and, as a 16 year old, Henry had very little freedom or spare time to pursue his own interests.

Henry Jaques served almost half his apprenticeship, and 'took to the trade', ${ }^{37}$ before he was abruptly dismissed on suspicion of stealing stock. According to his account he was innocent of all intent to steal, the incident was simply a misunderstanding, but he had left himself open to suspicion and, despite protestations, he was dismissed and 'left upon my beam ends without a character'. ${ }^{38}$ He then returned to his parents' home for some three months. His father tried to persuade him to return to the watch trade, but Henry would not do this. He helped his father by running messages, earned some money doing odd jobs for various people he knew, and taught himself carpentry. Eventually, through the good offices of his half-brother, he secured a position as an 'improver' at a small outfitters at a salary of $£ 12$ per annum.

He now changed employers frequently through a combination of his dissatisfaction with the work, his employers' dissatisfaction with him, and the effects of poor trade. At times he was quite fussy about where he went, leaving one employer after only a week in 1863 because 'It was a miserable home, bad food, an hypocritical master, morning prayers and nothing in the life to back it up ....39 and forming clear views on the relative desirability of the retail trade in different localities, ${ }^{40}$ most clearly articulated in 1860: "This was the second of the two offers I had previously had, but "pride" said don't go to the Boro, that low locality -

34 Morris, Women Workers; Schmiechen, Sweated Industries; Mudie-Smith, Sweated Industries.

35 'Life story', 21.

36 Ibid.

37 Ibid., 24

38 Ibid., 25.

39 Ibid., 40

${ }^{40}$ See Schmeichen, Sweated Industries, ch. 1. Also Hall, Industries of London; Stedman Jones, Outcast London. 
the "West of London" sounds better."41 Between February 1860 and April 1864 he had no fewer than seven different positions in the retail and wholesale drapery trade, progressing from an 'improver' through 'third', 'second' and 'first' hand to the post of assistant. Each time he changed posts he had a few weeks of unemployment, which he spent at his parents' home (they moved house several times but remained in the same area of Islington) and nearness to his parental home was an important consideration when he was seeking employment. For instance in 1861 he writes: 'I was out of a berth over a month, chiefly because I was waiting to secure one near home again'42 and although in each post he lived with his employer, his ability to maintain close contact with his parents was clearly important: "This shop was near home. I was able in 10 minutes to reach my home, which I often did after closing, for I loved my home, poor as it was. ${ }^{.43}$ Although on three occasions he did move outside the East End (to Pimlico, Marylebone and Brompton), he quickly returned to a more familiar area.

Working conditions in the retail and wholesale drapery trade were long and, as an assistant earning $£ 50$ per annum with an employer in Brompton Road in 1863, Henry Jaques was regularly working from 8 in the morning until 10 at night. Although now 21 years old, his life remained severely restricted by his employers and living conditions were spartan. For instance, whilst at Brompton Road he shared a bed with a more junior hand with whom, fortunately, he got on well. He notes that there was little time for activities outside work, though he continued to visit his parental home every Sunday. During this period he also met his future wife whilst delivering magazines for the local chapel (he had a fluctuating relationship with religion). They were married in 1864 and this forced a reappraisal of both his living and working arrangements.

For some ten years, between the ages of 12 and 22, Henry had been in employment, taking at least twelve different posts and living in as many places. However, although he moved frequently it was clearly important that he remained in contact with his home area of London. Throughout this period he lived with his employers, thus his journey to work was non-existent, but proximity to his parents' home remained important. He visited his parents almost every Sunday and on some evenings, and lived with them for several weeks when he was between posts. The frequent changes in work were partly precipitated by bad luck and a poor choice of employer, but they also reflected Henry's character. He seemed unwilling to settle to any one task for a long period and was constantly trying to improve himself without ever quite taking the right decision. Thus in one sense he was quite adventurous, he often initiated

\footnotetext{
41 'Life story', 41.

12 Ibid., 28.

13 Ibid., 27.
} 
change, and from time to time sought to improve himself both through education and religion. However, despite these characteristics his teenage years were in many ways highly constrained. He was closely controlled by a series of employers and by his parents, he had little free time, limited money and, by late twentieth-century standards, few opportunities.

\section{The impact of marriage on choice of home and workplace}

Although Henry Jaques had been making decisions about his employment and the location of his workplace for the previous ten years, his accommodation had followed automatically from whatever work he had. Impending marriage meant that he now had to assume a greater degree of responsibility and independence to ensure both a regular income and a home for his wife and the family that could be expected to follow. In fact, his decisions when to marry, where to live and what employment to take were all very closely interrelated. Henry clearly wished to marry reasonably quickly, but could not envisage how he might provide for a wife:

I was now formally 'engaged' to Lizzie, and ... I began to look to the future. I had certainly saved some money, and felt joy in so doing, if only in view of making a home for the one I loved, but the total amount was so small that the consummation of this desire seemed very remote.44

Henry sought advice from a Mr Isaac who had been manager of the shirt department at one of the wholesalers for whom Henry had worked. Eventually, this friend offered to contribute sufficient capital to enable Henry Jaques to set up on his own account as a retail draper and hosier. This was the solution that Jaques had been hoping for, but without the support of Mr Isaac he would have been unable to achieve it. As Henry puts it in his diary:

one day I called upon him [Mr Isaac] and he asked me how much money I had saved and whether I should like to go into business for myself in the retail. I told him I had saved nearly $£ 40$ and should indeed like to start on my own account, but my capital would not suffice. I had for long been thinking how little a business could be started upon and thought that to do this was the only way by which I could make a home for my Lizzie. This was my object when I left the Boro. and which I planned and worked for. ${ }^{45}$

Mr Isaac offered up to $£ 150$ at 5 per cent interest to add to Henry's own money to provide sufficient capital to start a business, but it was not without some trepidation that Henry Jaques accepted the offer: 
I did not rush at this proposal, but took two full weeks to consider it . . .

While writing this I feel amazed at my self confidence at that time - barely 22 years of age - and agreeing to go into business. ${ }^{46}$

Henry was clearly prepared to move almost anywhere in London to achieve his aim of a home and retail business:

I cast about to find a spot suitable for operations and compatible with my capital. I perambulated all over and around London until at last 275 Mile End Road was decided upon. The rent was $£ 55$ per annum upon lease for 21 years. ${ }^{47}$

His choice was in fact less than five kilometres from his home area in Islington and he consulted his step-brother (who was in the same trade) and another former employer about the suitability of the position. Mile End was to become the Jaques' home area for the next 13 years (see Table 1, Figures 1 and 3). The shop was in course of construction and he used his self-taught carpentry skills to equip it with fixtures and fittings. It is also clear that the timing of his marriage was fixed to enable the couple to run the business together and thus avoid employing an assistant:

Then it was thought that a more trustworthy assistant than a stranger would be found in a wife, also that the added cost of the one would not be more, or much more, than the other (?). ${ }^{48}$

They married on 27 April 1864 and spent a ten-day honeymoon staying with his aunt at her home in Shorne (Kent). During this period Henry made several trips to London to complete the fitting out of the shop and purchase stock, and the shop opened for business on 6 May. Money was very tight and Henry worried about his ability both to provide for his wife and succeed in business. He writes:

We returned to our new 'home' a few days before the opening day. The furniture did not take us long to arrange. We made a poor show, just the very barest of necessities. My poor dear Lizzie was - I could see - disappointed, but she said but little. All the money available had to go into the business leaving little to furnish with. We had all the large furniture on hire, and it took us 15 months to clear off.

I have since thought that, though it was a happy time to us, in one sense, still the terrible worry and anxiety, and foreboding of the future, tended to take the keen edge off our pleasure. After I had started upon the new task I was not happy in it and often wished myself in a situation again. ${ }^{49}$

Henry's forebodings about entering the retail trade on his own account were borne out by later events. Five months after his marriage

46 Ibid.
47 Ibid.
48 Ibid., 46.
49 Ibid., 47. 

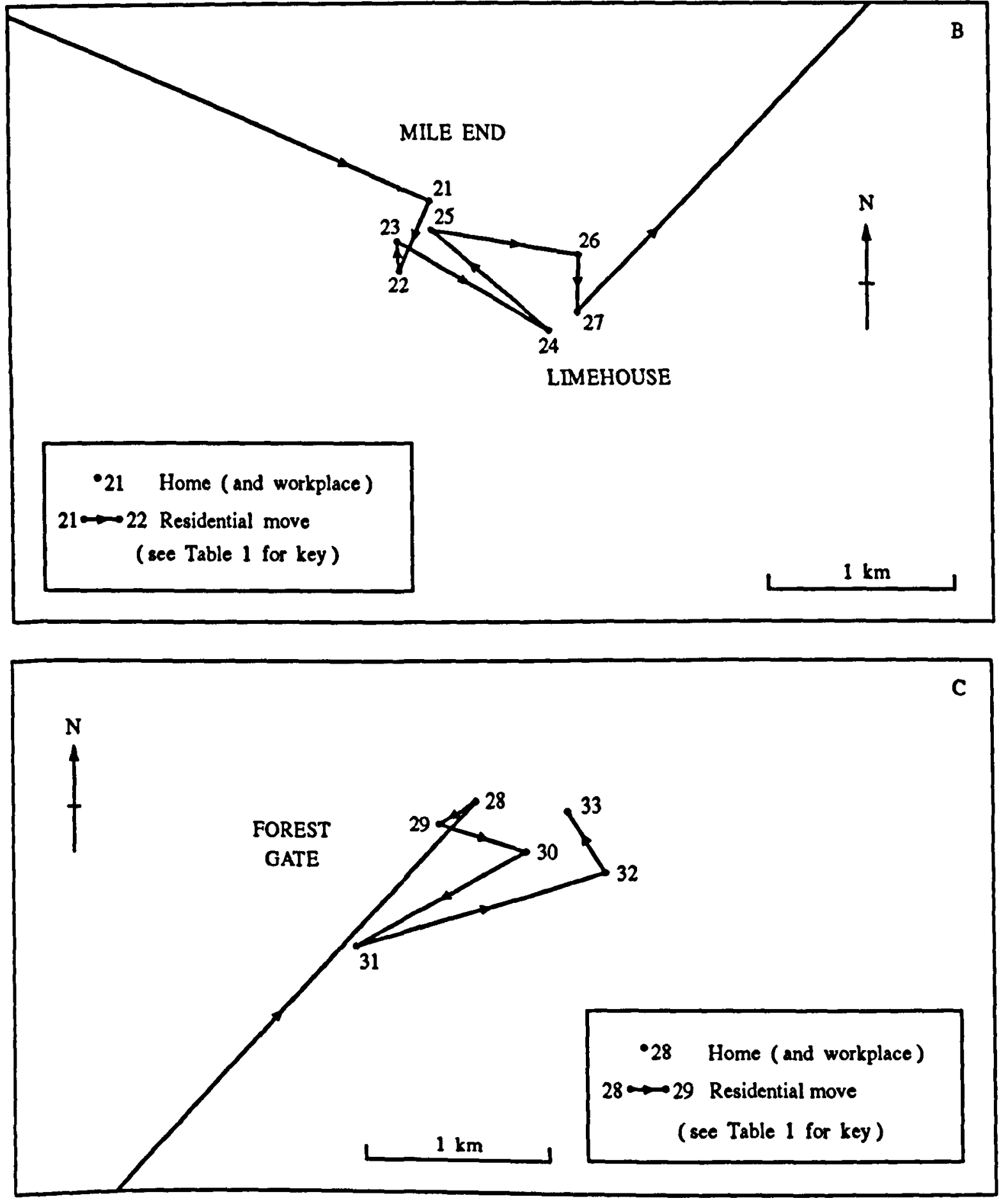

Figure 3: Details of residential moves undertaken by Henry Jaques in Mile End and Limehouse (1864-77) and in Forest Gate (1877-1907) Source: 'Life story of Henry Jaques' 
he was taken ill with rheumatic fever, the effects of which he felt throughout the rest of his life. He was ill for about a month, during which time his pregnant wife nursed him and ran the shop singlehanded. He then travelled to his aunt's at Doncaster to convalesce for two weeks before returning to work. Inevitably the business had been neglected during his illness, but thereafter takings began to rise and the Jaques sublet part of their house to increase their income. However, by the summer of 1866 the couple were in serious financial difficulties:

Many a time when the day came to take up a bill I found myself several pounds short and more than once had to seek the aid of the Pawnbroker for the time being. ${ }^{50}$

Mr Isaac offered to help by providing more capital to cover the debts and Henry Jaques entered into a financial arrangement which was eventually to lead to his downfall. Isaac would take responsibility for all outgoings, but all receipts would also be banked in his name and he charged 5 per cent for all money imported into the business. Writing retrospectively Jaques says:

it seems a marvel that anyone in his senses would agree to such terms, which virtually amounted to $5 \%$ per week for the use of the money. It would not be possible to have me thus now - but I was in a tight corner and very inexperienced in finance, and the desperate position was such that I did not probe into the future effects of this arrangement. ${ }^{51}$

The high interest being paid to Mr Isaac for his additional loans, together with a continuing lack of capital, meant that the business was doomed. Henry was effectively bankrupt, Mr Isaac took over the shop and paid off the creditors and Jaques was allowed to continue to live in the premises and manage the shop. This Henry agreed to do despite his loss of pride and the fact that he considered that Isaac had unlawfully extracted $£ 60$ from him during the business dealings. His main motive in staying in Mile End Road was the desire to provide a secure home for his wife and two young children. In fact, this was short-lived as, without informing Henry, Mr Isaac put the business up for sale. Everything except personal furniture was sold and, in July 1867, the Jaques moved to two rooms in Rectory Square, close to where the shop had been.

For several months thereafter, out of necessity, Henry continued to work for Isaac as a stock keeper in a City wholesale drapers some four kilometres from his home, but during his period in business he had also learned another skill which was to stand him in good stead in future years, and which also had an influence on future choices of employment and residence. In slack periods at the shop he taught himself the skill of shirtmaking, by taking apart a shirt in stock, cutting patterns, working

50 Ibid., 50.

51 Ibid. 
out adjustments for different sizes and experimenting with sewing them. By 1866 he was able to write:

I ... was eventually ... fully competant to cut out any kind of shirt and fit the most awkward customer. I advertised for work-hands and got together a small band, sufficient for my special orders, and had a ticket written for the window 'Shirts made to order and cut on the premises'. .2

By 1867 he had quite a thriving business, including making large quantities of shirts for wholesale as well as special orders for specific customers, with $\mathrm{Mr}$ Isaac putting substantial wholesale business his way. The expansion of this new business also had a substantial effect on his home life, and the demands made upon housing space:

Sewing machines were bought and a room set apart for the work room, dear Lizzie taking an active and prominant part in all the details, both of us working early and late to help on this work which supplemented the profits in the shop. And thus I was launched as a 'Shirt Manufacturer'. ${ }^{53}$

This additional income was too little and too late to save the Jaques from bankruptcy in the shop, but it did mean that they had an alternative source of income when they fell on hard times. Thus whilst living at Rectory Square, immediately after being evicted from the shop but still in the employ of Mr Isaac, Henry combined his work as stock keeper in a wholesale drapers with shirtmaking, leading to long hours but a reasonable income:

My duties were to keep stock, execute orders from all parts of the country, and after $6 \mathrm{o} / \mathrm{c}$ take home to the London customers orders which had accumulated. Sometimes there were too many to carry and I had to hire a wagonette and drive round. And then after reaching home, sometimes as late as 8 or $9 o / c$, would begin 'cutting out' until $12 \mathrm{o} / \mathrm{c}$ in the morning. My home business had increased somewhat, and, with care, my salary in the City $(25 /-)$ was supplemented by $10 /$ - to $12 /$ - per week. ${ }^{54}$

In his early married life Henry Jaques's home and workplace continued to be closely entwined. From living on the premises as an employee, he became proprietor of a small retail business, which meant that the security of his home was tied up with the fortunes of his business, a common experience in the retail trade. ${ }^{55}$ Even after his business collapsed, and he was forced to take work in the City (a journey to work of only some four kilometres), he continued also to work from home at the self-taught trade of shirtmaking He was thus part of the East End sweated clothing trade, though as a small employer rather than a

52 Ibid., 52.

53 Ibid.

54 Ibid., 55.

55 M. Winstanley, The Shopkeepers' World (Manchester, 1983); G. Shaw, The role of retailing in the urban economy', in Johnson and Pooley, Structure of Nineteenth Century Cities, 171-94. 
sweated worker. ${ }^{56}$ This pattern of activity was to dominate the rest of his life as decisions about where to live were closely tied into the relative success and demands of work both within and outside the home.

\section{Changing home and workplace with a growing family}

The economic demands of supporting a growing family, and the space needs associated with more children, are usually key factors in decisions about employment and residence during the family-building phase of the life cycle. ${ }^{57}$ Henry and Lizzie Jaques had a total of fourteen children between 1865 and 1888, with a maximum of ten living at home at any one time. In addition his parents joined the household for a period in the 1880s (when most of the children were still at home), and the homebased shirtmaking business - an essential supplement to his salary - also took up considerable space. Residential choice thus required a trade-off between relatively low cost, proximity to work in the retail or wholesale clothing trade, and sufficient space to accommodate a large family and home-based shirtmaking. Between 1867 and 1907 Henry and Lizzie lived in a further eleven houses and Henry worked for four different employers in a variety of capacities (Table 1, Figures 1 and 3). The adjustments in both employment and housing that were a feature of his early life continued to be important as his family grew and circumstances changed.

After only six weeks in the two rooms at Rectory Square, the Jaques moved round the corner to White Horse Lane in September 1867 where they rented more rooms specifically to provide additional space for shirtmaking. Henry saw this as a period not of absolute poverty, but of considerable deprivation:

Our bread was sure, but beyond this there were deprivations which we cannot enumerate. It was a fight, and a hard one. ${ }^{58}$

Not surprisingly, Henry Jaques severed his association with Isaac as soon as he could find alternative employment, and early in 1868 he entered into an engagement with a shirt manufacturer whom he knew from previous employment:

My duties were to cut out and make the shirts (at home). This was done in the early morning and after $4 \mathrm{o} / \mathrm{c} \mathrm{p.m.,} \mathrm{the} \mathrm{intervening} \mathrm{hours} \mathrm{being} \mathrm{occupied} \mathrm{in}$ travelling, soliciting orders for the goods we were making. ${ }^{59}$

He thus continued the pattern of combining the apparent security of

56 Morris, Women Workers, ch. 6; Schmiechen, Sweated Industries; Mudie-Smith, Sweated Industries.

57 Rossi, Why Families Mooe; Champion and Fielding, Migration Processes and Patterns, 165-87.

58 'Life story', 54.

59 Ibid., 55. 
employment by a wholesale firm with home working. His salary at this time was 30 s per week which, given that he would now have less opportunity to make shirts on his own account, was probably a little less than his previous total income. This level of income would have placed Henry Jaques just above the largest category of workers that Charles Booth identified in East London: those in Class $E$ with regular earnings of $27 \mathrm{~s}$ to $30 \mathrm{~s}$ per week. Of these workers Booth commented that with large families they were not lifted far above the poverty level, but that few were 'very poor'.60 This fits quite closely with Henry Jaques's own appraisal of his struggle to make ends meet.

The precariousness of employment in the London clothing trade is illustrated by the fact that later in 1868 Henry Jaques was once more forced to seek new employment:

I found it a stupendous task to solicit orders for a small unknown house ... so that it was finally decided to close it. This was not so serious a matter to Mr. Phillips as to me. He was the case of a wealthy sponge merchant, while I was again upon my beam ends. ${ }^{61}$

Having been let down by employers on several occasions, Henry Jaques now decided to concentrate on his home-based shirtmaking, and to solicit business from the City on his own account. He gained a number of substantial accounts, and rapidly required more space to carry out this business: 'Lodgings were of no use for this, so we took a house No. 5 Henry St. Rhodeswell Rd. Limehouse, where we had more room. ${ }^{62}$ However, despite moving, he remained in the same part of London, close to family and friends and able to exploit a familiar business and social community. Given that he was now manufacturing entirely on his own account, access to business contacts was particularly vital. In the same year he moved to another house in the same locality, again to provide more space for the increasing family (three children) and home work.

During this period Henry built up particularly good contacts with the wholesale merchants, Brown Davis \& Co. in the City, who took a large proportion of Jaques's output of shirts. Early in 1870 Jaques learned with some dismay that Brown Davis were to commence manufacture of all their own goods, and the buyer with whom he dealt asked Henry if he could recommend someone to be chief shirt cutter in their new department. With some hesitation Henry Jaques suggested himself for the position and was eventually taken on in May 1870 at a salary of $£ 115$ per year (plus dinner and tea), and with the possibility of also continuing his own home working if he wished. There was some reluctance among the senior partners to engage someone who was previously a self-employed

60 Booth, Life and Labour, 33-61.

61 'Life story', 56.

62 Ibid. 
shirtmaker, the suggestion being that shirt cutters were 'not a sober class of man', but Henry assured his future employer that he was a total abstainer. Henry was himself initially nervous about his new position, as he had not cut special orders for some years, but he made a good impression and satisfied his employers. This chance opening was to provide the most stable period of employment in Henry Jaques's life, as he remained with the same firm for fourteen years.

Early in 1871 the Jaques (now with four children) moved to Blomfield Road, Bow, remaining in the same part of London, but beginning to establish a pattern of moving slightly further from the city centre. However, Henry's employment in the City, to which he almost certainly always walked, kept the family well within the densely populated urban area. The combination of working as a shirt cutter in the City and at home meant that Henry was working long hours, leaving home at 6.30 a.m. and returning home by 7.00 p.m. He would then have his own outworkers to deal with, and spent most of the evening and often late into the night at his own cutting board. His wife took responsibility for taking orders and forwarding goods connected with the home working. Work left little time for other activities and the 'monotony of our daily life was broken only by illness and births'.63 There were substantial numbers of both.

The Jaques' family income must now have been substantial by the standards of many of London's poorer residents: in 1873 he earned at least $€ 155$ per annum from his main employment, ${ }^{64}$ plus income from a growing home-based shirtmaking business which included outworkers and a small machine room. In contrast, a survey of average wages in St George's-in-the-East in 1887 showed that even skilled workers such as carpenters and wheelwrights rarely earned more than 30 s per week and many unskilled workers earned less than 20s.65 In 1889 Charles Booth fixed his basic poverty level for a small family at $21 \mathrm{~s}$ per week and in the early twentieth century a woman employed in the sweated shirtmaking trade of East London could expect to earn little more than $5 s$ per week as a home worker. ${ }^{66}$ This was the sort of person that Henry Jaques employed to sew the shirts that he had cut out at home. However, despite this relatively high income Jaques complained both of poverty and, less surprisingly, overwork. In 1872 they moved a short distance again and he states:

With our five children we were compelled to have a larger house than my income warranted and the fight became very hard indeed - money would go out

63 Ibid., 60.

64 Though skilled cutters in a West End bespoke tailors could earn considerably more. See Green, 'Distance to work', 183-4.

65 Stedman-Jones, Outcast London, 215.

66 Mudie-Smith, Sweated Industries, 34-36, 129. 
faster than it came in. The work people had to be paid every week, but sometimes I had to wait weeks for the payment of my City accounts. ${ }^{67}$

Although his home working was succeeding, he was suffering the cash flow problems of many small businesses. He also acknowledges that life was hard for his wife:

But if it was hard for me, it was harder for the dear one. She had her home duties to perform, the machine room to superintend, besides doing some of the work. My heart often ached to see her dear wan face when she came in to see me at the board to wish me good night. ${ }^{68}$

In 1873 Henry gained unexpected promotion at Brown Davis, being offered the position of chief buyer and manager for the section of the department concerned with shirts, collars, shirtings and all linen goods with his salary increased to $£ 205$ per annum. In 1875 he was given control of the whole department with a further increase in salary. He now had a very responsible position, he travelled widely on business to places such as Manchester, Glasgow and Belfast, but worried about the finances of his department, continued with his home working and still complained of relative poverty in relation to his growing family:

We had no annual holidays then - I always had my two weeks at B.D. \& Co. but we seldom did more than go for daily trips. The children were all too young, and my purse too scanty to take them all away, so the holiday was more often, then, occupied in work at home. ${ }^{69}$

However, despite these protestations the Jaques family was clearly prospering and in 1877 considered a rather longer residential move than they had previously attempted. The immediate reason for moving to the suburbs was for the health of the family, but such a move must also have been a reflection of the growing affluence and status of Henry Jaques. He explains the move in some detail, and leaving the area in which he had lived for so many years must have been something of a wrench:

The health of my dear one and of the children was such that it was put into my heart to try and arrange to remove to a suburb of London.

The doctor was always in the house to one or another and, after mature thought and prayer, it was ultimately resolved that we should look out for a house away from these dense districts.

Very many families were leaving the district for the more salubrious air of Leytonstone and Forest Gate. These two Hamlets then were little more than villages. We were led to seek a house in the latter locality. It seemed a very gigantic business, but when once we were resolved the matter was followed up, and eventually we decided upon a small house at 28 Bignold Rd. at a rent of $£ 28$

67 'Life story', 60.

68 Ibid., 61.

69 Bbid., 67. 
per annum, where we removed in July 1877 and thus began our connexion with Forest Gate which was destined to be both happy and lasting. ${ }^{70}$

The move took Henry almost ten kilometres from his workplace in the City, presumably necessitating commuting by public transport (a tram line running directly from the edge of the City to Stratford, close to his home, had opened in $1870,,^{71}$ though its use is not explicitly mentioned), but he was less than six kilometres from his previous residences around the Mile End Road and could easily maintain contact with family and friends whilst enjoying the advantages of a more suburban environment. Contact with the area of London in which he had previously lived continued for some time as in 1880 he notes that:

We kept our membership at the East London Tab, for some years, attending at least monthly on the first Sunday for communion. Between times we attended the Forest Lane Congregational Chapel ...?

The household at the time of the move included seven children and both of Henry's parents who had joined them due to ill health in 1876. Henry's feelings towards this extension of his household were ambivalent:

For many years the tax upon us was great, and we felt the loss of the room with our still increasing family, but I was brought to see that what I was doing was my duty... ${ }^{73}$

Despite moving to a more suburban location, the Jaques continued to move home frequently, adjusting their housing to both demands for space and their income. In total the family undertook a further five moves in the suburbs (see Table 1 and Figure 3), typified by the experience of 1879 when they rented 5 Macdonald Villas, Forest Gate: ... a quaint house, but roomy, and cheap, this latter qualification being the chief reason for our removing from Bignold Road'. ${ }^{74}$ Despite increasing prosperity and a more suburban lifestyle, Henry Jaques continued with his home-based shirtmaking. The income provided was deemed essential, though clearly he had increasing aspirations which necessitated expenditure, especially on his children's education:

My home work assumed important proportions while here and supplemented my City salary considerably. Were it not for this it would have been impossible for us to have met all demands, nor to bring up the dear young ones in such a manner as to be fitted for the battle of life. ${ }^{75}$

He also made good use of the additional space at Macdonald Villas,

70 Ibid., 69-70.

71 Barker and Robbins, London Transport, 183-190.

72 'Life story', 73

73 Ibid., 71.

74 Ibid., 72.

73 Ibid. 
keeping poultry in the garden - which he found to be 'a profitable investment ${ }^{76}$ - and building a separate outhouse (chiefly using discarded material from an old warehouse which was demolished by the City firm for whom he worked) to use as a cutting room.

In 1884 , at the age of 42 , the job insecurity which had dominated Henry's earlier life returned to him at a time when he would be likely to find it increasingly difficult to compete in the labour market, and he also had considerable outgoings associated with a suburban home and a household consisting of ten children and two dependent parents living at home. Brown Davis, the City firm for whom he had worked for fourteen years, were clearly in decline and Henry wisely decided to leave before it collapsed. He took the position of sales representative with a small shirt manufacturer in Wood Street, a post secured through existing contacts in the shirt trade, and negotiated a profit-sharing contract which should have secured at least the income which he had previously enjoyed. Feeling secure in his employment the Jaques again moved house in Forest Gate:

to 28 Sebert Rd., a more comfortable house. The rent was more, but our prospects seemed then so good that we felt we were justified in making the change. ${ }^{77}$

However, once again things did not turn out as Henry had anticipated. Despite his considerable efforts as a travelling salesman the company did not succeed and he clearly had a serious personality clash with another employee of the firm. In 1886, and with some trepidation, Henry Jaques decided to cut his losses and leave despite having a relatively uncompetitive position in the labour market:

So, at the age of 44, I had to cast about and begin life afresh. But where, or how? ? 78 $^{2}$

Sometimes I was well nigh miserable, I pictured a season of poverty and misery for the dear ones. The market was inundated with 'young men'. Old ones were at a discount. It was then, as now, experience counted for little. Cheapness of labour was the great ideal of employers. ${ }^{79}$

In the event Henry was unnecessarily despondent. His experience, and especially his business contacts did count for something, and he was very quickly offered a position as commercial traveller for a good wholesale hosiery firm (Dent Allcroft, 97 Wood Street), with the specific task of securing new business in the suburbs of London. Henry's initial salary was $£ 25$ less per annum than he had previously been earning, and he began his new job with considerable foreboding relating both to the difficulty of acquainting himself with a much wider range of stock than

76 Ibid., 63.

77 Ibid., 78.

78 Ibid., 80.

79 Ibid., 81. 
he had previously been used to, and the task of securing business in unknown suburbs of the metropolis. Henry Jaques was successful in his work: in his first seven months employment he secured 179 new accounts for the company, but at considerable cost. He travelled long distances with a heavy bag of samples and his health, which had not been good since his attack of rheumatic fever, suffered considerably. He also continued to supplement his income with home working which placed a further strain upon him:

no one will ever know what the next seven months meant to me physically. The daily effort, involving long tedious walks between the many short drives by bus and train, the heavy weight of the bag, sometimes supplemented by a parcel in addition, the long and eamest talking to would-be customers, tiring in itself, and, when I arrived home, often and often at 8,9 and sometimes $10 \mathrm{o} / \mathrm{c}$ tired out, but only to have a snatch of a supper and then go to the cutting board for an hour or two. ${ }^{80}$

After several short periods of sickness, in January 1887 he was taken severely ill with bronchitis and pleurisy for four weeks, followed by two weeks convalescence in Bournemouth. Fortunately his employers wished to retain his services and recognized that the work was too strenuous. They increased his salary and arranged for him to have a brougham in which to travel around London with his samples. Henry continued to be a successful commercial traveller and stayed with the same firm until his death in 1907 . His relative prosperity and job security was also reflected in a move to 'a larger and more comfortable house's1 at Hamfrith Road in the same locality of London, where he was still living when the life history was compiled in 1901. The family moved twice more in the Forest Gate area in 1902 and 1905.

The final years of the life history generate few entries of interest. The family seemed settled to a suburban life of relative prosperity, but it was still interlaced with illness (Lizzie had a serious attack of tuberculosis in 1891) and with other family crises, mostly relating to their children. In summary, Henry's married life consisted of a constant adjustment of his employment and home situations. Although relatively successful and prosperous, life was not without its hardships, and his choice of house was determined not only by his income and job prospects, but also by proximity to City wholesalers and the availability of sufficient space for a growing family and home-based shirtmaking. Other influences on his life included the church, his family, and a desire for self-improvement, though at times it is clear that he had little time for anything other than work. 


\section{The wider context}

There is little point in trying to assess the typicality of a life history such as this. Its value lies in the detailed insight which it gives into the way in which one family adjusted their work and residences to suit changing circumstances. However, many of the processes affecting the Jaques would have influenced other families living in London at the time. The uncertainty of work, even for someone with reasonable skills and education, the difficulty of generating enough income to support a growing family and rising aspirations, the constant threat of illness, the ease with which families moved between similar rented property, the close ties between home and workplace, the stresses produced by home working, and the attractions of suburbanization for those who could afford it were all themes that were common to many families. The case study of Henry Jaques exemplifies many of these themes particularly effectively.

Very frequent short-distance residential mobility within one locality was a common feature of the migration pattern of many people in the past. Using data collected from family historians throughout Britain to construct a database of 16,091 lifetime residential histories for individuals born between 1750 and 1930,82 it has been found that over 38 per cent of all moves undertaken had an origin and destination in the same settlement. For moves with an origin in the County of London in the period 1840-1919 no fewer than 72.3 per cent had a destination in the metropolis. The pattern of intra-urban mobility within the County of London in the period 1840 to 1899 formed a complex web of moves, picking out the structure of separate neighbourhoods within London. Jaques's moves were typical of this wider pattern, but his removal to the residential suburb of Forest Gate eventually took him outside the County of London and into Essex.

As was the case with Henry Jaques, most intra-urban moves in the database collected from family historians were for a combination of employment, family and housing reasons. For all moves undertaken between 1840 and 1919 with an origin and destination in the same settlement, 31.5 per cent were undertaken for housing reasons, 25.0 per cent on marriage, 23.5 per cent for work-related reasons and 10.4 per cent for other family reasons or in response to personal crises. However, as the example of Henry Jaques has shown, such a simple classification of migration reasons is misleading, because employment, housing and family stimuli for movement were often closely linked together.

82 Collected as part of a research project on the longitudinal analysis of individual residential histories, supported by ESRC research grant R000234638. For further details of the data set, methodology and selected results see C.G. Pooley and J. Turnbull, 'Migration and urbanization in North-West England: a reassessment of the role of towns in the migration process', in D. Siddle (ed.), Migration, Mobility and Modernization in Europe (Liverpool, forthcoming 1997). 
Although Jaques moved more frequently than most people (the average number of lifetime moves undertaken by individuals in the family history database born between 1840 and 1899 was 5.3), in other respects the experience of Henry Jaques seems typical of wider experience and stresses the complex interrelationships of employment and life-course factors in stimulating migration.

The process of suburbanization occurred more rapidly in London than in any other British city, ${ }^{83}$ but even in the metropolis the distances over which most people travelled to work remained relatively short. ${ }^{84}$ Evidence from the family history database of lifetime residential histories suggests that the journey to work changed only slowly in the nineteenth century, and that it was not until after the First World War that the ties between home and workplace were broken, and improved urban transport systems linked to rising real incomes allowed longer-distance commuting for large numbers of people. ${ }^{85}$ Thus, although longer than in other parts of the country, the mean journey to work for those employed in London was only around five kilometres in the nineteenth century, whereas it doubled in the first thirty years of the twentieth century (Table 2). Professional workers on higher incomes had the longest journeys to work, but in the period 1850 to 1899 professional workers in London still only travelled on average $6.9 \mathrm{~km}$. from their home to their workplace. In contrast, skilled manual and craft workers travelled just $3.1 \mathrm{~km}$. Those living within the County of London had especially short journeys to work, for instance residents of East London (where Henry Jaques lived) on average travelled only $2.2 \mathrm{~km}$. from their home to their workplace in the period 1850-99. In contrast, those that lived outside London but worked in the metropolis had a mean journey to work of $33.5 \mathrm{~km}$. in the same period. The relatively restricted world in which the Jaques lived and worked was thus common to many London families in the second half of the nineteenth century. In the later, more affluent, stages of his life Jaques's journey to work was well above the average for all workers in London, but considerably lower than the mean for all those who lived outside the County of London but worked in the metropolis.

London was notable for the persistence of home working, especially in the East End clothing trade in which Jaques worked. It is estimated that there were over 100,000 home workers in London in 1900,86 often living and working in cramped and potentially dangerous conditions and earning as little as $4 s$ to $8 s$ per week. ${ }^{87}$ These were the workers that Jaques employed in his home-based shirtmaking, and who provided

83 Jackson, Semi-Detached London; Thompson, Rise of Suburbia; Dyos Victorian Suburb.

84 Dyos, 'Workmen's fares'; Green, 'Distance to work in Victorian London'.

85 Lawton, 'Journey to work in England and Wales'; Warnes, 'Journey to work distances'.

${ }^{86}$ Schmiechen, Sweated Industries; Morris, Women Workers.

${ }^{87}$ Mudie-Smith, Sweated Industries. 
Table 2: Changes in the journey to work in Britain

\begin{tabular}{lcc}
\hline \hline \multirow{2}{*}{ Date } & \multicolumn{2}{c}{$\begin{array}{c}\text { Mean journey to work }(\mathrm{km}) \\
\text { All workplaces }\end{array}$} \\
\hline $1750-1799$ & 2.6 & 1.7 \\
$1800-1849$ & 5.1 & 1.9 \\
$1850-1899$ & 4.4 & 2.5 \\
$1900-1929$ & 10.8 & 4.3 \\
$1930-1959$ & 21.0 & 7.2 \\
$1960+$ & 37.2 & 14.5 \\
& & \\
Total sample size & 4,957 & 18,891 \\
\hline \hline
\end{tabular}

Source: Data collected from family historians (see note 82)

many of the products which he sold in his other activities. Such working practices were clearly linked into an advanced capitalist economy as home workers were supplying large wholesale merchants who distributed goods throughout Britain and overseas. However, such production systems were a far cry from the organized 'Fordist' systems of large-scale factory production which had already emerged in some industrial sectors by the mid-nineteenth century, and which dominated British and European manufacturing industry in the first half of the twentieth century. ${ }^{88}$

The advantages of such production practices were that they lowered overhead costs for merchants and manufacturers who did not have to invest capital in their own workshops, and the flexible working arrangements meant that workers could change jobs easily and maximize their income in an uncertain labour market. The downsides of this system were the low wages and harsh working conditions experienced by many, and the uncertainty of employment with home workers not knowing from day to day whether their services would be needed by large City wholesalers. ${ }^{89}$

Henry Jaques was better off than many London workers, but clearly saw his home-based shirtmaking as an essential supplement to his income in the City. He clung to this work even when he was reasonably prosperous and living in a suburban location. It can be suggested that for people like Henry Jaques, home working also became a way of life.

88 D. Landes, The Unbound Prometheus: Technological Change and Industrial Development in Western Europe from 1750 to the Present (Cambridge, 1969); A. Millward and S. Saul, The Development of the Economies of Continental Europe, 1850-1914 (London, 1977); S. Lash and J. Urry, The End of Organized Capitalism (Oxford, 1987), 17-83; B. Jessop, Fordism and PostFordism: A Critical Reformulation (Lancaster, 1991); N. Gilbert, R. Burrows and A. Pollert (eds), Fordism and Flexibility: Divisions and Change (London, 1992).

${ }^{89}$ Morris, Women Workers; Schmiechen, Sweated Industries; Mudie-Smith, Sweated Industries. 
He identified himself as a shirtmaker, he possibly felt that he gained status by running a small home working enterprise, and his continued association with the cutting board appeared to be an important part of his lifestyle. It can be suggested that it was a combination of such economic and socio-psychological factors which encouraged the persistence of home working in the London clothing trades long after most other industries had adopted more centralized and organized working practices.

Many of the themes identified in the life history of Henry Jaques have echoes in the late twentieth century. These include the development of more uncertain and 'flexible' working arrangements in a post-industrial and post-Fordist disorganized capitalist economy, ${ }^{90}$ the under-capitalization and cash flow problems of small enterprises which have difficulty collecting payment from larger companies, ${ }^{91}$ the extent to which people and economies are dependent on the decisions of transnational companies who take decisions based on assessments of the global economy rather than the needs of local people and places,, 92 the problems that an older man has competing in a labour market where low cost is more important than experience, ${ }^{93}$ the stresses and strains produced by home working (especially for women who combine home working with domestic duties and child care), ${ }_{1}^{94}$ and the difficulty of matching housing space to income and need..$^{95}$ Although much has changed in the century

${ }^{90}$ Lash and Urry, The End of Organized Capitalism; Jessop, Fordism and Post-Fordism; Gilbert et al., Fordism and Flexibility; D. Massey, Spatial Divisions of Labour: Social Structures and the Geography of Production (2nd ed., London, 1995).

91 P. Lloyd and C. Mason, 'Spatial variations in new firm formation in the United Kingdom: comparative evidence from Merseyside, Greater Manchester and South Hampshire', Regional Studies, 18 (1984), 207-20; D. Goss, Small Businesses and Society (London, 1991); G. Reid, Small Business Enterprise: An Economic Analysis (London, 1993); D. Keeble et. al., New Firm Formation and Small Business Growth in the United Kingdom: Spatial and Temporal Variations and Determinants (Sheffield, 1993).

92 A. King (ed.), Culture, Globalization and the World System: Contemporary Conditions for the Representation of Identity (London, 1991); R. Robertson, Globalization: Social Theory and Global Culture (London, 1992); J. Dunning, The Globalization of Business: The Challenge of the 1990s (London, 1993); A. Amin and N. Thrift (eds), Globalization, Institutions and Regional Development in Europe (Oxford, 1994); D. Massey and P. Jess (eds), A Place in the World: Places, Cultures and Globalization (Oxford, 1995); M. Waters, Globalization (London, 1995).

93 P. Makeham, Economic Aspects of the Employment of Older Workers (London, 1980); C. Oliver, Older Workers and Unemployment (London, 1982); P. Robinson, Unemployment and Local Labour Markets (Aldershot, 1991); J. Michie and J. Grieve Smith (eds), Unemployment in Europe (London, 1994); M. White (ed.), Unemployment, Public Policy and the Changing Labour Market (London, 1994).

94 B. Bolton, An End to Homeworking (London, 1975); Trades Union Congress, Homeworking (London, 1978); C. Hakim and R. Dennis, Homeworking in Wages Council Industries: A Study Based on Wages Inspectorate Records of Pay and Earnings (London, 1982); H. Pugh, Estimating the Extent of Homeworking (London, 1984); S. Allen and C. Wolkowitz, Homeworking: Myths and Realities (London, 1987); A. Phizacklea and C. Wolkowitz, Homeworking Women: Gender, Racism and Class at Work (London, 1995).

$95 \mathrm{~J}$. Allen and C. Hamnett, Housing and Labour Markets: Building the Connections (London, 1991); Champion and Fielding, Migration Processes and Patterns, 41-77; P. Balchin, Housing Policy: An Introduction (London, 1995). 
178 Urban History

since Henry Jaques wrote his life story, many of the problems that the Jaques family had to overcome, and the decision-making process of matching employment, housing and life-cycle needs, would be remarkably familiar to a late twentieth-century household. 